\title{
THE INFLUENCE OF HUSBAND'S SUPPORT ON HEALTH-SEEKING BEHAVIOR IN MADURESE MOTHERS WITH POSTPARTUM BLUES
}

\author{
Adenia Dwi Ristanti, Elly Dwi Masita \\ Faculty of Nursing and Midwifery, Universitas Nahdlatul Ulama Surabaya
}

\begin{abstract}
ABSTARCT
Background: Postpartum blues or baby blues is a transient state of increased emotional reactivity experienced by some postpartum mothers within 14 days after delivery. Family support, especially the husband's role, is important to overcome the postpartum blues experience of mothers. This study aimed to determine the influence of husband's support on health-seeking behavior in Madurese mothers with postpartum blues.

Subjects and Method: This was a cross-sectional study conducted at Maron Community Health Center, Probolinggo, East Java, from April to June 2020. A total of 40 Madurese mothers with postpartum blues was selected for this study. Postpartum blues was measured by the Edinburgh Postnatal Depression Scale (EPDS). The dependent variable was health-seeking behavior. The independent variable was husband's support. The data were collected using questionnaire. Correlation between health-seeking behavior and husband's support was analyzed by Spearman rank correlation.
\end{abstract}

Results: Health-seeking behavior was positively correlated with husband's support $(r=0.95 ; \mathrm{p}$ $<0.001)$.

Conclusion: Health-seeking behavior is positively correlated with husband's support among women with postpartum blues.

Keywords: postpartum blues, mothers, health-seeking behavior, husband's support

\section{Correspondence:}

Adenia Dwi Ristanti. Faculty of Nursing and Midwifery, Universitas Nahdlatul Ulama Surabaya. Jl. Raya Jemursari No.57, Jemur Wonosari, Wonocolo, Surabaya, East Java, 60237. Email: adeniadr@unusa.ac.id. Mobile: +6285748160002. 